\title{
Thermoset Polymer Splicing Study Using a variation of welding
}

\section{Studi Penyambungan Bahan Polimer Termoset Menggunakan Variasi Pengelasan}

\author{
Adi Prastyo Utomo ${ }^{1}$, Prantasi Harmi Tjahjanti ${ }^{2}$ \\ \{ o111adiprastyo@gmail.com ${ }^{1}$, prantasiharmi@umsida.ac.id ${ }^{2}$ \}
}

Universitas Muhammadiyah Sidoarjo, Indonesia ${ }^{1}$, Universitas Muhammadiyah Sidoarjo, Indonesia ${ }^{2}$

\begin{abstract}
There is not much plastic welding currently done and not much research has been done on plastic welding. The purpose of this study was to study the use of welding variations used to join the thermoset polymer material. The thermoset polymer materials used are acrylic, melamine and bakelit with the test sample measuring 80mm in length, $30 \mathrm{~mm}$ in width and $3 \mathrm{~mm}$ in thickness. Variations in welding are used using hot gas welding, electric soldering and gas torches. The test method is carried out after welding to determine the porosity of the weld using a penetrant liquid. Hardness testing was also carried out. The best welding results are shown on acrylic material using electric solder, showing that the amount of porosity is the least, and has the highest hardness test.
\end{abstract}

Keywords - Thermoset polymer; acrylic; melami; bakelit; hot gas welding, electric soldering; gas torch; penetrant liquid test; hardness test

Abstrak. Pengelasan material plastik saat ini belum banyak dilakukan dan belum banyak penelitian yang membahas tentang las plastik. Tujuan penelitian ini adalah mempelajari pemakaian variasi pengelasan yang dipakai untuk menyambung bahan polimer thermoset. Bahan polimer termoset yang dipakai adalah akrilik, melamin dan bakelit dengan sample uji berukuran panjang $80 \mathrm{~mm}$, lebar $30 \mathrm{~mm}$ dan tebal $3 \mathrm{~mm}$. Variasi pengelasan yang dipakai menggunakan hot gas welding, solder listrik dan torch gas. Metode pengujian yang dilakukan setelah pengelasan untuk mengetahui porositas hasil las menggunakan penetrant liquid. Juga dilakukan uji kekerasan. Hasil pengelasan terbaik ditunjukan pada bahan akrilik dengan menggunakan solder listrik, memperlihatkan bahwa jumlah porositasnya yang paling sedikit, dan memiliki uji kekerasan tertinggi.

Kata Kunci - Polimer termoset; akrilik; melami; bakelit; hot gas welding, solder listrik; torch gas; uji penetrant liquid; uji kekerasan

\section{Pendahuluan}

Plastik merupakan suatu benda yang cukup banyak digunakan manusia. Namun plastik juga memiliki kekurangan yaitu tidak tahan terhadap panas dan mudah retak atau pecah, apabila barang yang terbuat dari plastik tersebut sudah mengalami kerusakan keretakan atau pecah maka hampir sudah bisa dipastikan barang tersebut sudah tidak bisa digunakan lagi. Untuk menyiasati supaya barang tersebut bisa dipakai kembali dan mengurangi pembuangan sampah plastik maka diperlukan perbaikan secara khusus. Tidak bias dipungkiri bahwa dewasa ini semakin banyak teknik pengelasan yang sangat penting digunakan pada keperluan konstruksi baik dari segi otomotif hingga bangunan yang membutuhkan keterampilan dan sebuah pengalaman untuk mendapatkan hasil sambungan pengelasan yang baik dan kuat. Apabila plastik tersebut mengalami keretakan atau pecah untuk memperbaikinya adalah dengan cara di sambung menggukanan las plastik dengan elektroda yang sama dengan induk plastik tersebut secara umum untuk plastik yang dibedakan berdasarkan sifat mekanik dan thermal menjadi tiga macam yaitu Thermoplast, Thermoset dan Elastomers. Thermoset adalah jenis plastik yang dibentuk melalui proses pengawetan atau pengerasan dengan suhu lebih dri $200^{\circ} \mathrm{C}$ hal ini menyebabkan terjadinya rangkaian antara rantai polimer menjadi sangat kuat akibat dari ikatan ini thermosets bisa menahan suhu yang tinggi yang apabila dipanaskan tidak dapat kembali seperti semula dan mengalami kerusakan pada susunan molekul sampai suhu plastik tersebut turun oleh karena itu sangat sulit untuk melakukan perbaikan pada plastik jenis thermoset apabila mengalami kerusakan hal itu terjadi karena reaksi kimia terjadi selama pemrosesan dan menyembuhkan dalam kasus thermoset, yaitu, sebagai akibat dari reaksi cross-link yang tidak dapat diubah dalam cetakan. Keduanya membentuk termos dan komponen elastomer yang divulkanisasi tidak dapat dibentuk kembali dengan menggunakan panas, karena membentuk ikatan reaksi kimia yang ireversibel yang terjadi selama proses pendinginan termoset tidak meleleh meskipun dipanaskan akan tetapi terurai dan tidak berubah saat didinginkan dan dengan demikian dalam hal ini penyambungan dapat diperoleh dengan pengikatan mekanis dan ikatan perekat saja. [1] 
Plastik atau biasa disebut dengan polimer merupakan material yang tersusun dari gabungan banyak unit monomer yang tergabung dan berulang hingga membentuk polimer. Material ini adalah material yang cukup banyak digunakan dalam kehidupan sehari-hari karena sifat plastik yang mudah dibentuk sehingga memudahkan untuk membuat benda dengan bentuk yang rumit dengan melakukan proses pencetakan pada plastik tersebut. Sifat plastik yang ringan memudahkan untuk seseorang menjadikan barang-barang yang digunakan sehari-hari baik untuk perabotan rumah tangga seperti tempat makanan. [1]

Ada beberapa teknik las plastik yaitu : hot gas hand welding, hot gas extrusion welding, butt fusion (heated element welding), laser welding dan high frequency welding. Pada kenyataannya yang paling dikenal luas dalam fabrikasi termoplastik adalah hot gas hand welding. Hot gas plastics welding adalah proses manual untuk menyambung material termoplastik, dengan menggunakan aliran tekanan udara panas yang di arahkan untuk memanaskan dan melelehkan material termoplas dan kawat lasnya. Penyambungan terjadi karena fusi bersama antara substrat lembaran plastik tadi dengan kawat lasnya. Dalam metode pengelasan ini tidak membutuhkan suhu yang tinggi hanya sampai pada titik suhu dimana elektroda untuk pengelasan bisa menjadi lunak

\section{METODE}

Penelitian ini dilaksanakan dalam beberapa tahapan yang sudah disusun. Tahap persiapan, pada tahap ini dilakukan persiapan mulai dari survey ke tempat bengkel las plastik yang ada di kota Malang untuk melihat proses pengelasan plastik, pembelian material seperti akrilik, kabelit dan melamin dan alat seperti hot gas welding, solder listrik dan torch gas untuk keperluan pengelasan las plastik, kemudian dilakukan proses pengelasan material dengan menggunakan elektroda yang sama dengan material induk dengan menggunakan variasi metode pengelasan yang berbeda. Pada tahap akhir dilakukan proses pengujian pada material utuh sebagai perbandingan dan pengujian terhadap material yang telah dilakukan penyambungan menggunakan las plastik.

Pemilihan material sebelum melakukan proses pengelasan guna mempermudah dalam pencarian material yang mudah didapatkan. Dalam proses pengelasan ini pemilihan alat las plastik juga penting karena alat yang digunakan berbeda dengan pengelasan logam

Pada penelitian kali ini pengelasan dilakukan secara bertahap dan berdasarkan jenis materialnya dari pengelasan material akrilik menggunakan elektroda akrilik, dengan menggunakan metode pengelasan menggunakan hot gas welding, solder listrik dan torch gas. Langkah pertama adalah mengamplas kedua ujung permukaan akrilik sebelum dilas kemudian dekatkan kedua permukaan yang sudah di amplas kemudian lakukan pengelasan. Lakukan langkah yang sama untuk masing-masing metode pengelasan. Pengelasan material selanjutnya yaitu pengelasan melamin menggunakan elektroda melamin, dengan menggunakan metode pengelasan menggunakan hot gas welding, solder listrik dan torch gas. Pengelasan material terakhir adalah pengelasan material bakelit denagn menggunakan metode pengelasan menggunakan hot gas welding, solder listrik dan torch gas. Untuk langkah-langkah pengelasan mengunakan cara atau metode yang sama seperti yang dilakukan pada saat pengelasan akrilik. Dari pengelasan berbagai macam material tersebut dibuat dalam beberapa jumlah untuk sampel pengujian.

Proses pengujian pengelasan dilakukan dalam beberapa uji yang dilakukan pada setiap sampel, uji yang dilakukan yaitu uji penetrant liquid test. Pengujian penetran adalah proses pengujian sambungan las tanpa merusak material proses pengujian penetran hanya dilakukan pada sampel yang telah dilakukan proses penyambungan menggunakan las plastik baik material yang di las denagn menggunakan metode pengelasan menggunakan hot gas welding, solder listrik dan torch gas. Uji penetran ini berfungsi untuk mengetahui porositas terhadap sambungan las yang telah dilakukan apabila memenuhi syarat yang diinginkan maka akan dilanjutkan pada proses uji selanjutnya.

Langkah-langkah untuk melakukan uji liquid penetrant adalah sebagai berukut :

1. Bersihkan permukaan sambungan pengelasan menggunakan cleaner/remover dengan cara menyemprotkan cairan cleaner kemudian lakukan pengelapan menggunakan kain lap bersih tunggu hingga mengering.

2. Langkah kedua semprotkan cairan red penetrant dengan merata sampai menutupi sambungan las yang sudah dibersihkan kemudian tunggu hingga 10 menit supaya cairan red penetrant menutup dengan sempurna.

3. Bersihkan cairan red penetrant yang telah disemprotkan pada sambungan pengelasan hingga benar-benar bersih dengan menggunakan kain lap bersih yang sudah diberi semprotan cairan cleaner/remover kemudian tunggu hingga mengering.

4. Langkah terakhir adalah penyemprotan cairan developer pada sambungan las yang telah dibersihkan dari cairan red penetrant. Semprotkan cairan developer pada permukaan sambungan las hingga tertutup dengan sempurna kemudian tunggu beberapa saat hingga cairan developer mengering.

5. Amati reaksi yang terjadi apabila banyak terdapat bintik-bintik merah pada sambungan pengelasan artinya adalah sambungan pengelasan terdapat banyak porositas.

6. Lakukank langka-langkah tersebut pada setiap material dengan menggunakan metode pengelasan yang berbeda. 


\section{HaSil dan Pembahasan}

Penelitian ini dilakukan untuk menganalisis pengaruh parameter proses pada kekuatan sambungan sambungan las menggunakan metode pengelasan hot gun welding, solder listrik dan torch gas terhadap beberapa sampel material uji yang terdiri dari bahan akrilik, bakelit dan melamin. Pengaruh parameter masukan terhadap kualitas las telah dipelajari melalui inspeksi dan pengujian. Pengujian yang dilakukan yaitu uji liquid penetrant untuk mengetahui porositas pada sambungan las. Hasil percobaan menunjukkan bahwa hasil yang diperoleh berbeda-beda dari setiap material yang sudah dilakukan pengelasan. Hasil percobaan menunjukkan bahwa hasil yang diperoleh berbeda-beda dari setiap material yang sudah dilakukan pengelasan. Setelah dilakukan pengamatan terhadap masing-masing spesimen uji yang telah dilakukan menggunakan beberapa metode pengelasan dan perpaduan material maka didapat data seperti yang di bahas pada bab ini beserta dengan analisa dan pengamatan pada setiap pengujian yang telah dilakukan guna memberi gambaran terhadap beberapa proses hasil pengelasan dengan beberapa material termoset yang berbeda.

Penyambungan pada material akrilik dikakukan dengan menggunakan tiga cara yaitu menggunakan hot gas welding, solder listrik dan torch gas. Dengan dilakukannya menggunakan tiga metode pengelasan yang berbeda dan variasi suhu yang berbeda dari setiap metode pengelasan untuk mengetahui pengaruh sifat plastic termoset terhadap perlakuan panas selama proses pengelasan. Penyambungan pada material akrilik menggunakan hot gas welding dilakukanmemberikan semburan udara panas yang berasal dari hot gas welding terhadap sambungan akrilik yang sudah ditempelkan kedua ujung akrilik tersebut dengan suhu rata-rata yang dihasilkan oleh hot gas welding adalah $208^{\circ} \mathrm{C}$. Dan hasil yang diperoleh dari pengelasan akrilik menggunakan metode hot gas welding adalah akrilik dapat tersambung, dikarenakan disaat akrilik diberikan semburan udara panas maka akrilik tersebut merubah sifat akrilik menjadi lentur seperti karet dan kemudian sedikit meleleh menjadi cairan yang lengket. Hasil pengelasan akrilik menggunakan hot gas welding seperti ditunjukkan pada gambar 1.

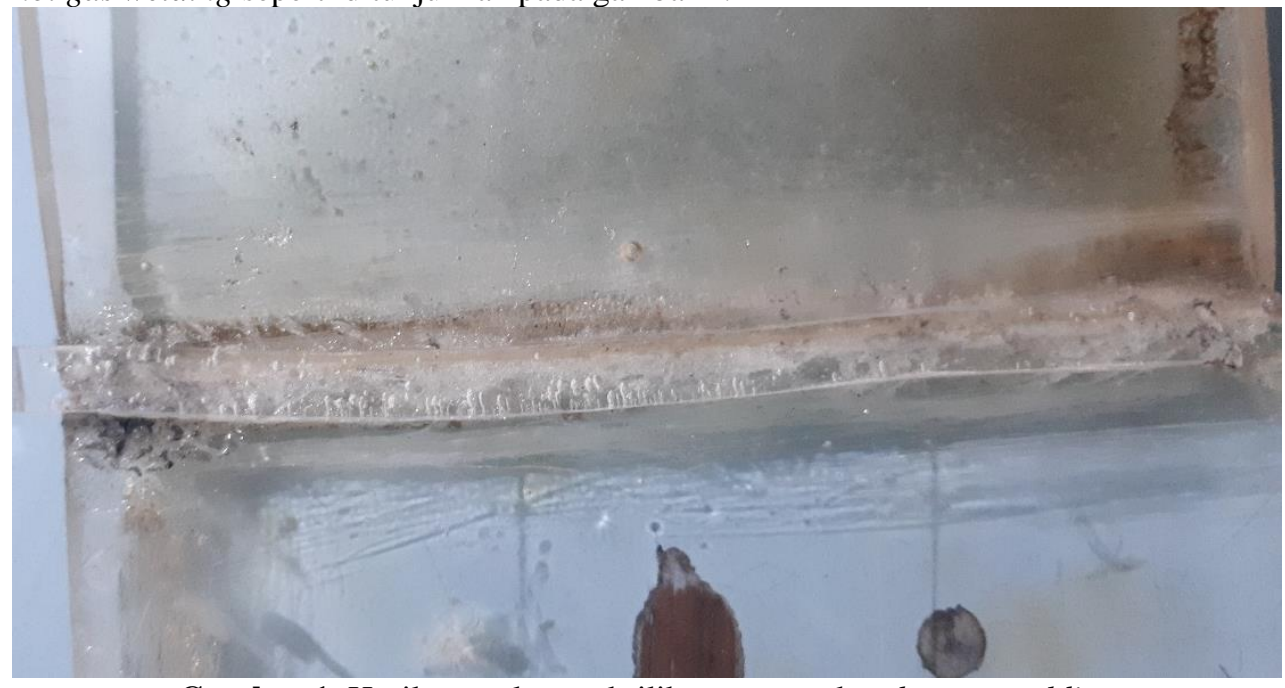

Gambar 1. Hasil pengelasan akrilik menggunakan hot gas welding

Penyambungan pada material akrilikmenggunakan solder listrik dengan suhu rata-rata $223^{\circ} \mathrm{Cdan}$ membutuhkan waktu 4 detik untuk melelehkan akrilik. penyambungan dilakukan dengan menempelkan ujung mata solder listrik pada kedua permukaan ujung akrilik yang sudah di amplas sampai kedua ujung permukaan akrilik sedikit meleleh, proses ini dilakukan sampai seluruh sambungan akrilik tertutup. Berikut ini adalah gambar permukaan akrilik yang sudah disambung menggunakan solder listrik seperti ditunjukkan pada gambar 2 . 
Procedia of Engineering and Life Science Vol. 1. No. 1 March 2021

Seminar Nasional \& Call Paper Fakultas Sains dan Teknologi (SENASAINS 1st)

Universitas Muhammadiyah Sidoarjo

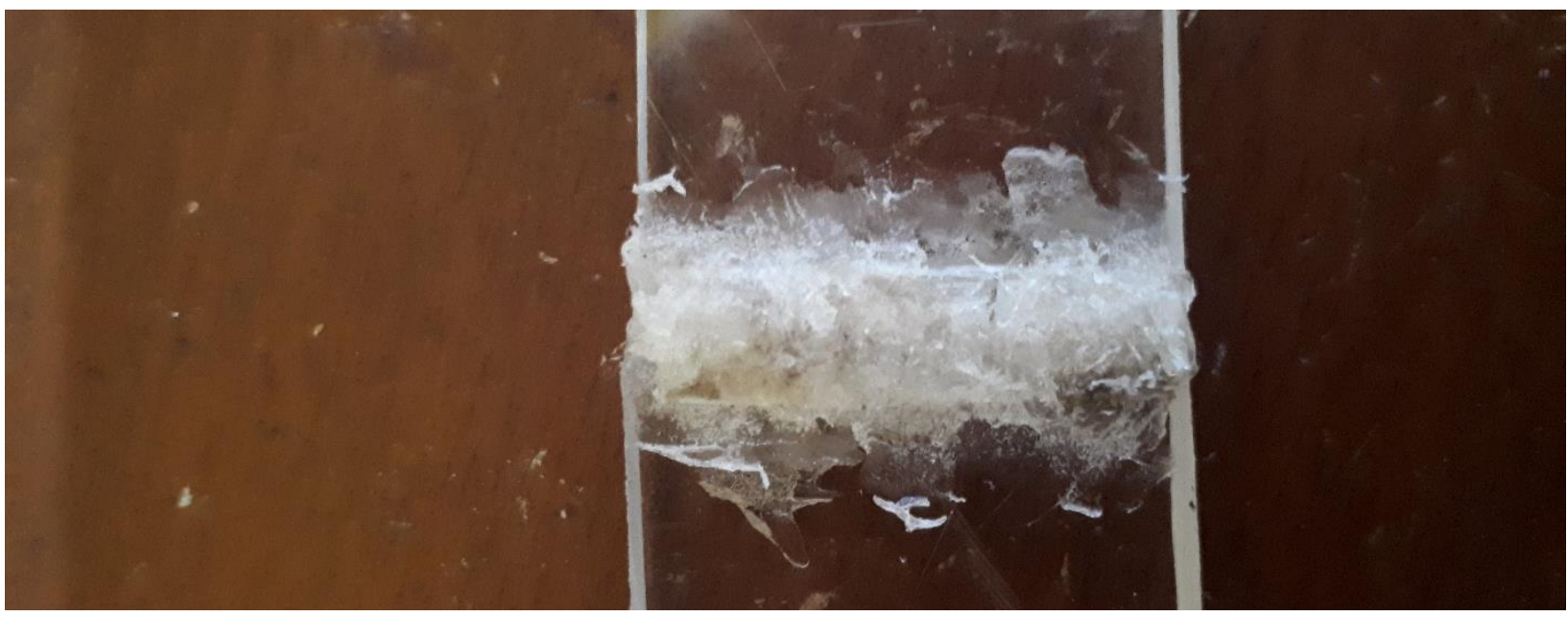

Gambar 2. Hasil pengelasan akrilik menggunakan solder listrik

Penyambungan pada material akrilik menggunakan torch gas sama halnya dengan yang dilakukan seperti metode sebelumnya menggunakan nyala api terhadap permukaan akrilik yang akan disambung. Suhu yang digunakan pada metode pengelasan ini adalah $189^{\circ} \mathrm{C}$ waktu pengelasan yang deperlukan yaitu ke 5 detik. Hasil dari pengelasan akrilik menggunakan torc gas adalah material akrilik pada detik ke 3 saat dilakukan pengelasan hasilnya akrilik langsung menjadi lentur dan pada detik ke 5 akrilik terbakar dikarenakan titik leleh akrilik cukup rendah yaitu $160{ }^{\circ} \mathrm{C}$ dan mengalami penyusutan volume pada saat proses ini akrilik belum tersambung dan ditunggu untuk beberapa saat hingga ke detik ke 7 hingga akrilik berubah menjadi sedikit kecoklatan dan permukaannya menjadi kasar. Hasil dari pengelasan menggunakan metode ini akrilik tersambung tapi akrilik meninggalkan bekas terbakar dan ketika diuji porositas menggunakan liquid penetrant adalah hasil porositas nya cukup tinggi dikarenakan akrilik terbakar saat proses pengelasan dan menimbulkan banyak lubang-lubang kecil. Gambar hasil pengelasan menggunakan metode torch gas seperti ditunjukkan pada gambar 3 .

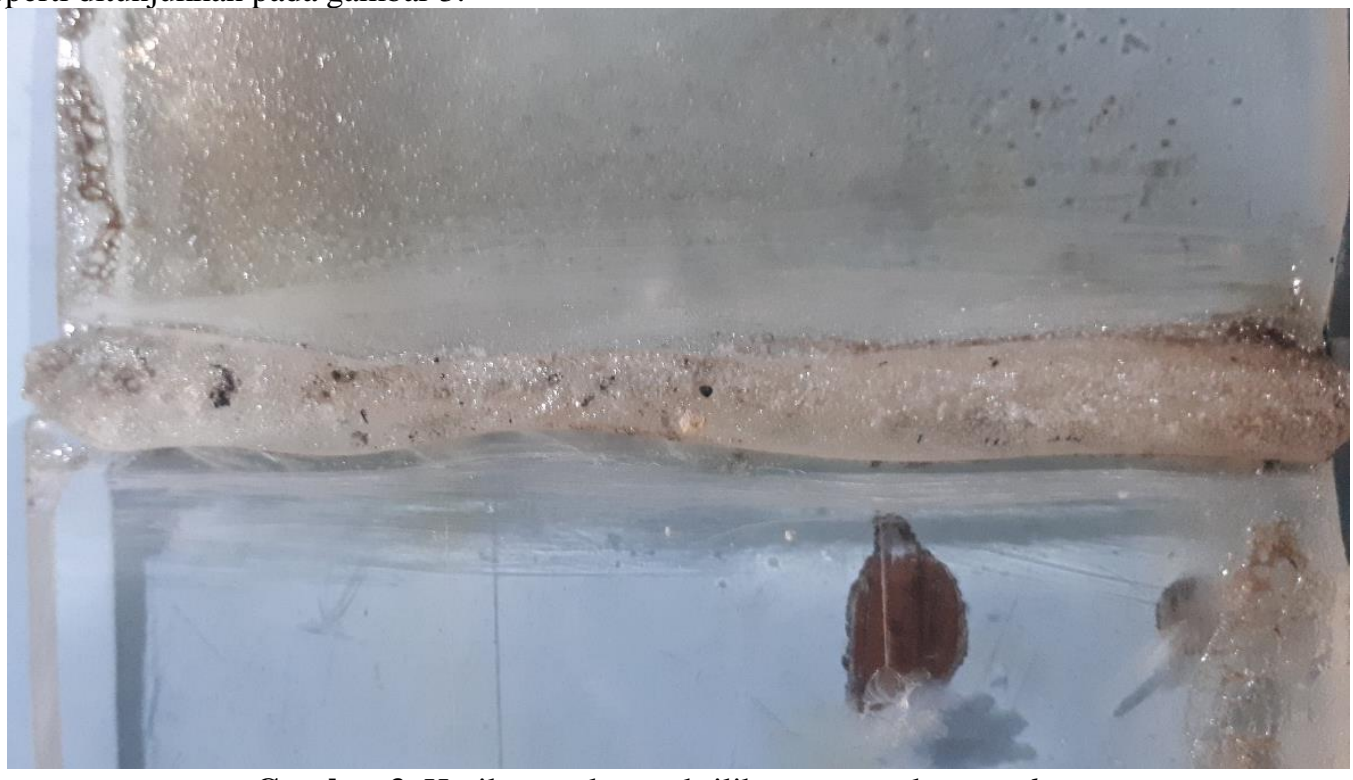

Gambar 3. Hasil pengelasan akrilik menggunakan torch gas

Setelah dilakukan proses pengelasan kemudian hasil sambungan akrilik dilakukan proses uji liquid penetrant untuk mengetahui porositas pada sambungan pengelasan.Hasil dari liquid penetrant test menunjukkan bahwa porositas pada sambungan pengelasan akrilik adalah kurang begitu baik dikarenakan pada saat proses pengelasan menggunakan metode ini paling susah dilakukan karena solder listrik tidak bisa melelehkan akrilik dengan baik.

Rincian penyambungan dari bahan akrilik menggunakan beberapa metode pengelasan ditunjukkan pada tabel 1 .

\begin{tabular}{|c|c|c|c|c|c|c|}
\hline \multirow[t]{2}{*}{ No } & \multirow[t]{2}{*}{ Material } & \multirow[t]{2}{*}{ Suhu } & \multirow{2}{*}{$\begin{array}{l}\text { Waktu } \\
\text { (detik) }\end{array}$} & \multirow{2}{*}{$\begin{array}{c}\text { Metode } \\
\text { pengelasan }\end{array}$} & \multicolumn{2}{|c|}{ Hasil } \\
\hline & & & & & tersambung & $\begin{array}{c}\text { Tidak } \\
\text { tersambung }\end{array}$ \\
\hline 1 & Akrilik & $208^{\circ} \mathrm{C}$ & 7 & hot gas welding & ya & - \\
\hline
\end{tabular}




\begin{tabular}{c|c|c|c|l|l|l}
\hline $\mathbf{2}$ & Akrilik & $223^{\circ} \mathrm{C}$ & 4 & solder listrik & Ya & - \\
\hline $\mathbf{3}$ & Akrilik & $189^{\circ} \mathrm{C}$ & 7 & torch gas & Ya & - \\
\hline
\end{tabular}

Penyambungan pada material melamin juga dikakukan dengan menggunakan tiga cara yaitu menggunakan hot gas welding, solder listrik dan torch gas. Penyambungan pada material melamin menggunakan hot gas welding tidak bias dilakukan karena suhu titik lebur melamin yaitu $345^{\circ} \mathrm{C}$ sedangkan suhu aktual yang dihasilkan oleh hot gas welding jauh dibawah suhu titik lebur melamin yaitu rata-rata berkisar antara $180^{\circ} \mathrm{C}$ sampai dengan $200^{\circ} \mathrm{C}$. pada saat dilakukan pemanasan melamin tidak bereaksi terhadap apapun saat permukaan melamin terkena gas panas yang di hasilkan oleh hot gas welding.

Penyambungan pada material melamin berukuran panjang $50 \mathrm{~mm}$ x lebar $25 \mathrm{~mm}$ x tebal $2 \mathrm{~mm}$ menggunakan solder listrik hasilnya adalah tidak bias dilakukan karena melamin mempunyai sifat kekerasan yang sangat tinggi dan ketahanan pada suhu panas yang sangat tinggi yaitu berkisar antara $345^{\circ} \mathrm{C}$, sedangkan solder listrik yang dipakai untuk penyambungan hanya memiliki suhu berkisar antara $223^{\circ} \mathrm{C}$. pada saat dilakukan pengelasan menggunakan solder listrik melamin tidak mengalami reaksi apapun saat ujung mata solder menyentuh permukaan dari melamin tersebut yang terjadi hanyalah melamin berubah warna menjadi sedikit memudar. Hasil dari permukaan melamin setelah dilakukan pemanasan menggunakan solder listrik seperti ditunjukkan pada gambar 5.

Penyambungan pada material melamin dengan ketebalan $2 \mathrm{~mm}$ yang sudah dipotong dengan ukuran panjang $50 \mathrm{~mm}$ x $25 \mathrm{~mm}$ menggunakan torch gas dilakukan dengan nyala api kecil dengan suhu rata-rata $189^{\circ} \mathrm{C}$. Hasil yang diperoleh pada proses penyambungan melamin menggunakan hot gas welding adalah tidak bisa dilakukan, karena apabila terkena api secara langsung dengan suhu $189^{\circ} \mathrm{C}$ akan membakar melamin tersebut karena akan merusak jaringan struktur melamin tersebut meskipun belum mencapai suhu yang melebihi batas ketahanannya yaitu $345^{\circ} \mathrm{C}$ dimana hal tersebut akan merusak ikatan rantai molekul silang pada melamin yang mana akan langsung membakar melamin dan berubah menjadi arang, dikarenakan sifat melamin yang keras karena termasuk jenis termoset yang akan rusak jika terkena api secara langsung, karena pada umumnya melamin digunakan untuk menghidangkan makanan dengan suhu hampir mencapai titik didih air bukan untuk memasak dan terkena api secara langsung. Rincian penyambungan dari bahan melamin menggunakan beberapa metode pengelasan ditunjukkan pada table 2 .

Tabel 2. Variasi pengelasan material melamin

\begin{tabular}{ccccccc} 
No & Material & Suhu & $\begin{array}{c}\text { Waktu } \\
\text { (detik) }\end{array}$ & $\begin{array}{c}\text { Metode } \\
\text { pengelasan }\end{array}$ & Hasil \\
tersambung & $\begin{array}{c}\text { Tidak } \\
\text { tersambung }\end{array}$ \\
\hline 1 & Melamin & $208^{\circ} \mathrm{C}$ & - & hot gas welding & - & Tidak \\
2 & Melamin & $223^{\circ} \mathrm{C}$ & - & solder listrik & - & Tidak \\
3 & Melamin & $189^{\circ} \mathrm{C}$ & - & torch gas & - & Tidak
\end{tabular}

Penyambungan pada bakelit juga dikakukan dengan menggunakan cara sbelumnya cara yaitu menggunakan hot gas welding, solder listrik dan torch gas. Penyambungan pada material bakelit menggunakan metode pengelasan hot gas welding tidak dapat dilakukan karena pada saat gas dari hot gas welding menyentuh permukaan bakelit walaupun dengan waktu yang cukup lama tidak dapat melelehkan bakelit namun hanya memanaskan permukaan bakelit hal ini dikarenakan bakelit memiliki sifat ketahanan termal yang sangat baik karena dalam produksinya bakelit banyak digunakan sebagai isolator maupun peralatan kelistrikan rumah tangga seperti saklar stop kontak dan lainlainnya.

Penyambungan pada material bakelit menggunakan metode pengelasan solder listrik dilakukan pada specimen uji yang sudah dipotong dengan ukuran panjang $50 \mathrm{~mm}$ x lebar $25 \mathrm{~mm}$ x tebal $2 \mathrm{~mm}$. suhu yang digunakan pada solder listrik untuk menyambung bakelit yaitu berkisar $223^{\circ} \mathrm{C}$. tidak bisa dilakukan meskipun material bakelit memiliki sifat kekerasan yang sangat baik dan juga mempunyai ketahanan termal yang sangat tinggi akan tetapi bakelit tidak mudah meleleh hanya menumbilkan bekas warna kecoklatan saat mata solder listrik secara langsung menyentuh permukaan bakelit. Maka dari itu penyambungan bakelit menggunakan torch gas tidak bias dilakukan.

Penyambungan pada material bakelit menggunakan metode pengelasan torch gas dilakukan pada dua buah material bakelit yang sudah dipotong dengan ukuran panjang $50 \mathrm{~mm}$ x lebar $25 \mathrm{~mm}$ x tebal $2 \mathrm{~mm}$, kedua material tersebut didekatkan hingga saling berdekatan, pada pengelasan kali ini dilakukan tanpa menggunakan kawat pengelasan karena disaat permukaan bakelit terkena api dari torch gas dengan suhu $189^{\circ} \mathrm{C}$ hasilnya adalah bakelit tersebut tidak melunak karena sifat bakelit sebagai termoset, saat dipanaskan maka bakelit langsung berubah warna menjadi kecoklatan sebelum akhirnya terbakar dan menjadi arang. Hasilnya adalah bakelit tidak bias disambung menggunakan api dikarenakan api akan merusak susuna ikatan silang antar rantai molekul yang dimiliki oleh bakelit. meskipun material bakelit memiliki sifat kekerasan yang sangat baik dan juga mempunyai ketahanan termal yang sangat tinggi akan tetapi bakelit akan terbakar dan menjadi arang saat terkena api. Maka dari itu penyambungan bakelit menggunakan torch gas tidak bias dilakukan. Rincian penyambungan dari bahan bakelit menggunakan beberapa metode pengelasan ditunjukkan pada table 3 . 
Tabel 3. Variasi pengelasan material bakelit

\begin{tabular}{cccclcc}
\hline No & Material & Suhu & $\begin{array}{c}\text { Waktu } \\
\text { (detik) }\end{array}$ & $\begin{array}{c}\text { Metode } \\
\text { pengelasan }\end{array}$ & tersambung & $\begin{array}{c}\text { Tidak } \\
\text { tersambung }\end{array}$ \\
\hline 1 & Bakelit & $208^{\circ} \mathrm{C}$ & - & hot gas welding & - & Tidak \\
2 & Bakelit & $223^{\circ} \mathrm{C}$ & - & solder listrik & - & Tidak \\
3 & Bakelit & $189^{\circ} \mathrm{C}$ & - & torch gas & - & Tidak
\end{tabular}

\section{KESIMPULAN}

Dari beberapa pengujian pengelasan polimer termoset dengan material akrilik, melamin dan bakelit dengan proses pengelasan menggunakan hot gas welding, solder listrik dan torch gas diperoleh hasil bahwa material melamin dan bakelit tidak dapat dilakukan penyambungan dengan metode hot gas welding, solder listrik maupun torch gas, hal ini dikarenakan sifat khas bahan polimer jenis plastik termoset biasanya bersifat keras karena mereka mempunyai ikatanikatan silang yang terbentuk dari molekul-molekul monomer berbentuk jaring yang besar. Jika bahan ini dipanaskan, maka molekul-molekul akan masih bergerak dalam lingkungan keseimbangannya sehingga tetap memberikan sifat yang keras dan tidak menjadi lembek. Material yang dapat tersambung hanyalah material akrilik menggunakan metode pengelasan memakai hot gas welding, solder listrik dan torch gas. Akrilik dapat tersambung karena sifat bahan akrilik memiliki kekerasan yang lebih rendah dari melamin dan bakelit sehingga bias menjadi lunak ketika dipanaskan. Pada pengujian sambungan pengelasan menggunakan liquid penetrant test masih terdapat cukup banyak porositas hal ini dikarenakan pada saat penyambungan kawat las akrilik tidak bias meleleh dengan sempurna hanya berubah tekstur menjadi lebih lunak sebelum akhirnya mengeras hal ini menyebabkan sulitnya penyambungan yang dilakukan pada akrilik sehingga mengakibatkan porositas yang cukup tinggi pada sambungan pengelasan.

\section{UCAPAN TERIMA KASIH}

Ucapan terimakasih yang pertama kepada Allah SWT yang telah member kemudahan atas setiap kesulitan yang dihadapi saat penelitian yang dilakukan, yang kedua kepada dosen pembimbing yang selalu sabar membantu member arahan dan masukan saat penelitian dan yang terakhir kepada teman-teman seperjuangan teknik mesin UMSIDA yang telah memberi semangat dan motivasi.

\section{REFERENSI}

[1] S. Haque and M. A. Siddiqui, "Plastic Welding : Important Facts and Developments," vol. 1, no. 2, pp. 1519, 2016. 